\title{
RESTORATIVE JUSTICE \\ SEBAGAI ALTERNATIF PERLINDUNGAN HUKUM TERHADAP \\ KORBAN KEKERASAN DALAM RUMAH TANGGA
}

\author{
Rena Yulia*
}

\begin{abstract}
The victim of domestic violence had needed of protection concept that different with another victim of violent crime. Participation of victim has want to give justice for all. It is, because punishment to offender brings the impact for victim. Restorative justice is a concept in criminal justice system which is participation victim with it. The present of criminal justice system is the offender oriented. Victim has not position to considerate offender punishment. Only offender can get the right and the victim hopeless. In the domestic violence, victim and offender have relationship. Because there are a family.-So, probability they have some interest in economic and relation. When wife become a victim and husband as offender, his wife has dependency economic from her husband. It means, if husband get a decision from judge, his wife will be suffer. Domestic violence is different crime. So, it is necessary to made some different concept. In this article, will discussed about alternative of legal protection for victim of domestic violence in criminal justice system to protect the victim.
\end{abstract}

Kata kunci: restorative justice, korban, criminal justice system

\section{Pendahuluan}

Dalam penegakan hukum, kelemahan mendasar adalah terabaikannya hak korban kejahatan dalam proses penanganan perkara pidana maupun akibat yang harus ditanggung oleh korban kejahatan karena perlindungan hukum terhadap korban kejahatan tidak mendapat pengaturan yang memadai. ${ }^{1}$

"Dosen Tetap Fakultas Hukum Universitas Islam Bandung, alamat korespondensi: rena_yulia@yahoo.co.id. 2005), hal. 2.

'Sidik Sunaryo, "Kapita Selekta Sistem Peradilan Pidana", (Malang: UMM Pres, 
Hal ini dapat dilihat dalam KUHAP, sedikit sekali pasal-pasal yang membahas tentang korban, pembahasannyapun tidak fokus terhadap eksistensi korban tindak pidana melainkan hanya sebagai warga negara biasa yang mempunyai hak yang sama dengan warga negara lain. Terlihat dengan bermacam-macamnya istilah yang digunakan dalam menunjuk seorang korban. $^{2}$

Korban kejahatan yang pada dasarnya merupakan pihak yang paling menderita dalam suatu tindak pidana, justru tidak memperoleh perlindungan sebanyak yang diberikan oleh undang-undang kepada pelaku kejahatan. Akibatnya, pada saat pelaku kejahatan telah dijatuhi sanksi pidana oleh pengadilan, kondisi korban kejahatan seperti tidak dipedulikan sama sekali. Padahal masalah keadilan dan penghormatan hak asasi manusia tidak hanya berlaku terhadap pelaku kejahatan saja, tetapi juga korban kejahatan. ${ }^{3}$

Dalam kaitan pemeriksaan suatu tindak pidana, sering kali korban hanya diposisikan sebagai pemberi kesaksian, sebagai pelapor dalam proses penyidikan, dan sebagai sumber informasi, atau sebagai salah satu kunci penyelesaian perkara. Sebaliknya, pada saat korban tidak dapat memenuhi kewajibannya sebagai saksi di persidangan, ia dikenakan sanksi. ${ }^{4}$

Perlindungan hukum terhadap korban selama ini baru mencapai taraf keadilan prosedural $^{5}$ belum mencapai keadilan substansial ${ }^{6}$. Padahal

${ }^{2}$ Istilah lain yang menunjuk terhadap korban adalah terdapat dalam Pasal 80-81 KUHAP: pihak yang berkepentingan. Pasal 98-99: pihak yang dirugikan. Pasal 108: Pengadu atau pelapor.

${ }^{3}$ Dikdik M. Arief Mansur dan Elisatris Gultom, "Urgensi Perlindungan Korban Kejahatan Antara Norma dan Realita”, (Jakarta: PT. RajaGrafindo Persada, 2007), hal. 24.

\section{${ }^{4}$ Ibid, hal 27.}

${ }^{5}$ Keadilan yang mengacu pada bunyi undang-undang an sich, <http://gp-ansor.org>, "Thomas aquino, kedilan prosedural yang berhubungan dengan keadilan dan kelayakan prosedur-prosedur yang digunakan untuk mengalokasikan kepentingan-kepentingan organisasi", <www.suaramerdeka.com>, diakses tanggal 28 Desember 2008. "Keadilan prosedural adalah hasil persetujuan melalui prosedur tertentu dan mempunyai sasarn utama peraturan-peraturan, hukum-hukum, undang-undang. Prosedur ini tidak bisa lepas dari upaya legitimasi tindakan", <www.kompas.com>, diakses tanggal 28 Desember 2008, "Keadilan yang lahir hanya karena melaksanakan kaedah formil dan materil peraturan perundangundangan".

6 "Keadilan yang berhubungan dengan objek legislasi hukum positif yang terkandung di dalam setiap bentuk hukum yang berlaku. Dengan keadilan substansif setiap bentuk hukum yang berlaku pada dasarnya merupakan manifestasi ikatan yurisdiksi dan mendistribusikan beban atas dasar kesamaan yang proporsional", <http://books.google.co.id>, "Keadilan yang lebih mendekatkan diri dan mendengar jeritan korban". 
eksistensi korban dalam suatu pelanggaran terhadap hukum pidana menjadi bagian integral dari sistem peradilan pidana. Hal ini berimplikasi terhadap harus diakuinya kepentingan korban. Untuk itu diperlukan pemberdayaan posisi korban dalam sistem peradilan pidana sebagai upaya perlindungan hukum secara substansial.

Dalam penanganan perkara pidana, kepentingan korban sudah saatnya untuk diberikan perhatian khusus, selain sebagai saksi yang mengetahui terjadinya suatu kejahatan juga karena kedudukan korban sebagai subjek hukum yang memiliki kedudukan sederajat di depan hukum (equality before the law). ${ }^{7}$

Kedudukan korban yang tidak mendapat tempat dalam proses peradilan pidana dikarenakan sistem peradilan pidana yang berlaku sekarang menganut keadilan retributif (retributive justice), penyelesaian perkara hanya semata-mata ditujukan untuk menjatuhkan sanksi kepada pelaku kejahatan tanpa mempertimbangkan aspek kerugian yang diderita korban. Penjatuhan sanksi semata-mata untuk pembalasan terhadap pelaku tanpa memulihkan kerugian yang diderita oleh korban.

Begitu juga dalam penyelesaian kasus kekerasan dalam rumah tangga (selanjutnya disebut KDRT) konsep yang digunakan masih menggunakan retributive justice. Pelaku harus bertanggungjawab secara individu kepada negara tetapi tidak mempertimbangkan kerugian yang diderita oleh korban sehingga korban tidak mendapatkan keadilan yang sebenarnya, malah mungkin akan terjadi viktimisasi sekunder.

Oleh karena itu, Undang-undang Nomor 23 Tahun 2004 tentang Penghapusan Kekerasan Dalam Rumah Tangga dibentuk agar dapat memberikan perlindungan hukum terhadap korban KDRT, mengingat sistem hukum yang berlaku sekarang belum menjamin perlindungan terhadap korban KDRT.

Undang-undang Nomor 23 Tahun 2004 tentang Penghapusan Kekerasan Dalam Rumah Tangga mengatur tentang hak-hak korban dalam memperoleh keadilan melalui sistem peradilan pidana sehingga tujuannya tidak hanya menindak pelaku KDRT tetapi juga melindungi korban KDRT.

Kasus KDRT merupakan kasus tindak pidana yang pelaku maupun korbannya merupakan orang dekat baik secara emosional maupun hubungan keluarga. Sehingga sangat dimungkinkan adanya hubungan kepentingan baik secara psikologis maupun ekonomis di antara pelaku dan korban ${ }^{8}$ dan secara logis memang demikian.

${ }^{7}$ Dikdik M. Arief \& Elisatris Gultom, Op. Cit., hal. 31. 


\section{Permasalahan}

Dari uraian tersebut, permasalahan yang akan dibahas adalah apakah konsep retributive justice telah memberikan perlindungan hukum terhadap korban KDRT dan menawarkan konsep restorative justice sebagai alternatif dalam memberi perlindungan terhadap korban kasus KDRT.

\section{Pembahasan}

Mengenai batasan definisi kekerasan dalam rumah tangga ini dirumuskan dalam Pasal 1 angka 1 Undang-undang Nomor 23 Tahun 2004 tentang Penghapusan Kekerasan Dalam Rumah Tangga, adalah:

Kekerasan dalam rumah tangga adalah setiap perbuatan terhadap seseorang terutama perempuan, yang berakibat timbulnya kesengsaraan atau penderitaan secara fisik, seksual, psikologis, dan/atau penelantaran rumah tangga termasuk ancaman untuk melakukan perbuatan, pemaksaan, atau perampasan kemerdekaan secara melawan hukum dalam lingkup rumah tangga. ${ }^{9}$

Kekerasan dalam rumah tangga tersebut dapat terjadi dengan cara sebagaimana yang terdapat dalam Pasal 5 Undang-undang Nomor 23 Tahun 2004 tentang Penghapusan Kekerasan Dalam Rumah Tangga ${ }^{10}$, yaitu sebagai berikut:

${ }^{8}$ Data kasus KDRT yang ditangani oleh LSM Jaringan Relawan Independen (JARi) periode April 2002 - November 2008. Januari - Desember 2008 terdapat 59 kasus KDRT, jumlah ini meningkat dari tahun sebelumnya yaitu Januari - Desember 2007 sebanyak 55 kasus. Januari - Desember 2006 terdapat 42 kasus KDRT setelah tahun sebelumnya yaitu Januari - Desember 2005 sebanyak 34 kasus. Januari - Desember 2004 sebanyak 19 kasus KDRT dan tahun sebelumnya yaitu Januari - Desember 2003 sebanyak 19 kasus juga. Melihat grafiknya terlihat adanya peningkatan jumlah kasus KDRT.

${ }^{9}$ Bandingkan dengan definisi yang terdapat dalam Pasal 1 Deklarasi Penghapusan Kekerasan terhadap Perempuan, 1993 : setiap tindakan berdasarkan perbedaan jenis kelamin (gender-based violence) yang berakibat atau mungkin berakibat kesengsaraan atau penderitaan perempuan secara fisik, seksual atau psikologis, termasuk ancaman tindakan tertentu, pemaksaan atau perampasan kemerdekaan secara sewenang-wenang, baik yang terjadi di depan umum atau dalam kehidupan pribadi.

${ }^{10}$ Bandingkan, Pasal 2 Deklarasi Penghapusan Kekerasan Terhadap Perempuan, PBB (1993): 


\section{Setiap orang dilarang melakukan kekerasan dalam rumah tangga terhadap orang dalam lingkup rumah tangganya, dengan cara:}

\section{1. kekerasan fisik; \\ 2. kekerasan psikis; \\ 3. kekerasan seksual;atau \\ 4. penelantaran rumah tangga.}

Dari uraian di atas bentuk-bentuk kekerasan dalam rumah tangga paling tidak meliputi 3 hal yaitu kekerasan fisik, psikis dan seksual. Adapun mengenai penelantaran dalam rumah tangga adalah merupakan suatu pengembangan dari ketiga bentuk kekerasan sebelumnya. ${ }^{11}$

Korban $^{12}$ kekerasan dalam rumah tangga ini dapat meliputi suami, istri, anak atau pun orang yang menetap dalam lingkup rumah tangga

a. kekerasan secara fisik seksual dan psikologis terjadi dalam keluarga, termasuk pemukulan, penyalahgunaan seksual atas perempuan kanak-kanak dalam rumah tangga, kekerasan yang berhubungan dengan mas kawin, perkosaan dalam perkawinan, pengrusakan alat kelamin perempuan dan praktik-praktik kekejaman tradisional lain terhadap perempuan, kekerasan di luar hubungan suami/pasangan isteri dan kekerasan yang berhubungan dengan eksploitasi;

b. kekerasan secara fisik, seksual dan psikologis yang terjadi dalam masyarakat luas, termasuk perkosaan, penyalahgunaan seksual, pelecehan dan ancaman seksual di tempat kerja, dalam lembaga-lembaga pendidikan dan sebagainya, perdagangan perempuan dan pelacuran paksa;

c. kekerasan secara fisik, seksual dan psikologis yang dilakukan atau dibenarkan oleh negara, dimanapun terjadinya.

11 Lihat pula Rika Saraswati, "Perempuan dan Penyelesaian Kekerasan dalam Rumah Tangga", (Bandung: Citra Aditya Bakti, 2006), hal. 21-27.

${ }^{12}$ Menurut Arif Gosita yang dimaksud dengan korban adalah:

Mereka yang menderita jasmaniah dan rohaniah sebagai akibat tindakan orang lain yang bertentangan dengan kepentingan diri sendiri atau orang lain yang mencari pemenuhan kepentingan diri sendiri atau orang lain yang bertentangan dengan kepentingan hak asasi yang menderita. Lihat Arif Gosita, Masalah Korban Kejahatan, (Jakarta: CV Akademika Pressindo, 1993), hal 65.

Korban juga didefinisikan oleh van Boven yang merujuk kepada Deklarasi Prinsipprinsip Dasar Keadilan bagi Korban Kejahatan dan Penyalahgunaan Kekuasaan sebagai berikut :

Orang yang secara indivual maupun kelompok telah menderita kerugian, termasuk cedera fisik maupun mental, penderitaan emosional, kerugian ekonomi atau perampasan yang nyata terhadap hak-hak dasarnya, baik karena tindakan (by act) 
tersebut. Korban KDRT berhak untuk memperoleh hak-haknya sebagaimana yang telah diatur dalam undang-undang ini. ${ }^{1}$

Dengan adanya pasal yang memuat tentang hak-hak korban ini maka diharapkan korban kekerasan dalam rumah tangga akan mendapat perlindungan dari negara dan/atau masyarakat sehingga tidak mengakibatkan dampak traumatis yang berkepanjangan. Sesuai dengan konsideran UU Penghapusan Kekerasan Dalam Rumah Tangga, korban kekerasan dalam rumah tangga, yang kebanyakan perempuan harus mendapat perlindungan dari negara dan/atau masyarakat agar terhindar dan terbebas dari kekerasan atau ancaman kekerasan, penyiksaan, atau perlakuan yang merendahkan derajat dan martabat kemanusiaan.

Namun dalam penyelesaian perkara pidana, seringkali hukum terlalu mengedepankan hak-hak tersangka/terdakwa, sementara hak-hak korban diabaikan. Banyak ditemukan korban kejahatan kurang memperoleh perlindungan hukum yang memadai, baik perlindungan yang sifatnya immateriil maupun materiil. Korban kejahatan ditempatkan sebagai alat bukti yang memberi keterangan yaitu hanya sebagai saksi sehingga kemungkinan bagi korban untuk memperoleh keleluasaan dalam memperjuangkan haknya adalah kecil. ${ }^{14}$

Korban tidak diberikan kewenangan dan tidak terlibat secara aktif dalam proses penyidikan dan persidangan sehingga kehilangan kesempatan untuk memperjuangkan hak-hak dan memulihkan keadaannya akibat suatu kejahatan. ${ }^{15}$

maupun karena kelalaian (by omission)... lihat Theo Van Boven, Mereka yang Menjadi Korban, (Yogyakarta: Pustaka Pelajar, 2002), hal. xiii.

${ }^{13}$ Dalam Undang-undang Nomor 23 Tahun 2004 tentang Penghapusan Kekerasan Dalam Rumah Tangga hak-hak korban adalah sebagai berikut:

Korban berhak mendapatkan :

a. perlindungan dari pihak keluarga, kepolisian, kejaksaan, pengadilan, advokat, lembaga sosial, atau pihak lainnya baik sementara maupun berdasarkan penetapan perintah perlindungan dari pengadilan;

b. pelayanan kesehatan sesuai dengan kebutuhan medis;

c. penanganan secara khusus berkaitan dengan kerahasiaan korban;

d. pendampingan oleh pekerja sosial dan bantuan hukum pada setiap tingkat proses pemeriksaan sesuai dengan ketentuan peraturan perundang-undangan; dan

e. pelayanan bimbingan rohani.

${ }^{14}$ Dikdik M. Arief \& Elisatris Gultom, Op. Cit., hal. 25-26.

${ }^{15}$ Chaerudin dan Syarif Fadillah, "Korban Kejahatan dalam Perspektif Viktimologi dan Hukum Pidana Islam", (Jakarta: Grhadhika Press, 2003), hal. 49. 
Perlindungan hukum terhadap korban Kekerasan dalam Rumah Tangga ${ }^{16}$ selama ini didasarkan pada KUHP sebagai sumber hukum materil, dengan menggunakan KUHAP sebagai hukum acaranya.

Perlindungan hukum bagi korban seharusnya diatur secara eksplisit dalam KUHP. Misalnya dalam menjatuhkan pidana terhadap pelaku dipertimbangkan juga kerugian yang diderita oleh korban atau keluarga korban. Sehingga pelaku bisa saja di berikan pidana ganti rugi yang mungkin akan lebih bermanfaat bagi korban.

Akses korban terhadap proses peradilan juga mesti diperhatikan. Korban berhak mengetahui perkembangan kasusnya. Apalagi apabila berkaitan dengan pelaku yang tidak mampu bertanggungjawab, maka korban juga dimungkinkan untuk mendapat kompensasi.

Begitu pula apabila dilihat dalam KUHAP, pengaturan mengenai korban sama sekali termarjinalkan. KUHAP lebih banyak mengatur mengenai perlindungan terhadap tersangka, sedangkan perlindungan terhadap korban tidak terumuskan secara lengkap.

Hak yang diberikan KUHAP terhadap korban sangat terbatas. Diantaranya dapat ditemukan dalam Pasal 98-101 KUHAP. Dalam pasal ini diatur mengenai satu-satunya mekanisme ganti kerugian yang bisa dijalankan oleh korban yaitu melalui mekanisme Pasal 98 KUHAP yang disebut penggabungan perkara gugatan ganti kerugian.

Tujuan dari penggabungan gugatan ganti kerugian ini adalah menyederhanakan proses perkara perdata yang timbul dari tindak pidana. Namun kerugian yang ditimbulkan hanya terbatas pada kerugian materiil saja, yaitu penggantian biaya yang telah dikeluarkan oleh korban, tidak mencakup pada penggantian kerugian immateril. Sehingga pada prakteknya, belum memenuhi kepentingan korban tindak pidana secara utuh.

Apabila dikaitkan dengan korban KDRT, tentu pelaksanaannya akan lebih rumit lagi, hal itu disebabkan korban KDRT tidak hanya dapat mengalami kekerasan fisik melainkan dapat juga mengalami kekerasan psikis yang tidak mungkin dapat dirumuskan dalam kategori kerugian materiil.

16 Pengertian korban menurut Undang-undang Nomor 23 Tahun 2004 tentang Penghapusan Kekerasan Dalam Rumah Tangga adalah orang yang mengalami kekerasan dan/atau ancaman kekerasan dalam lingkup rumah tangga. Lihat The Declaration of Basic Principles of Justice for Victims of Crime and Abuse of Power, PBB (1985), yang dimaksud dengan korban (victim) adalah orang-orang yang secara individual atau kolektif, telah mengadakan penderitaan, meliputi penderitaan fisik atau mental, penderitaan emosi, kerugian ekonomis atau pengurangan substansial hak-hak asasi, melalui perbuatan-perbuatan atau pembiaran-pembiaran (omission) yang melanggar hukum pidana yang berlaku di Negaranegara anggota, yang meliputi juga peraturan hukum yang melarang penyalahgunaan kekuasaan. 
Kemudian Pasal 108 ayat (1) KUHAP yang mengatur mengenai hak untuk mengajukan laporan atau pengaduan kepada penyelidik dan atau penyidik secara lisan maupun tertulis atas tindak pidana yang dialami. Dalam pasal ini, korban hanya dianggap sebagai saksi atau pelapor saja.

Kedudukan Korban KDRT yang melaporkan kejadiannya kemudian hanya dianggap sebagai saksi atau pelapor saja membuat mereka menjadi korban yang kedua kali ketika masuk dalam sistem peradilan pidana.

Dengan demikian, kedudukan korban dalam sistem peradilan pidana hanya sebagai pelengkap dalam suatu proses peradilan. Hal ini disebabkan KUHAP yang berlaku sekarang lebih berorientasi terhadap pelaku dari pada terhadap korban. Sistem peradilan pidana yang berorientasi terhadap pelaku inilah yang disebut dalam tesis ini sebagai konsep retributive justice.

Cara kerja sistem peradilan pidana dalam kerangka retributive justice adalah setiap faset sistem peradilan pidana bekerja dengan mereduksi korban, pelanggar, dan masyarakat untuk menjadi partisipan yang pasif. Korban bukan pihak-pihak berkepentingan dalam kasus kejahatan, tetapi korban adalah warga negara (masyarakat) menjadi saksi, jika diperlukan, bagi penuntutan. Korban memiliki kontrol yang sangat terbatas terhadap apa yang terjadi dan tidak bertanggung jawab terhadap tahapan dari proses peradilan. ${ }^{17}$

Posisi hukum korban kejahatan tidak diakui dalam sistem peradilan pidana. Korban kejahatan hanya bertindak sebagai - pelapor dan saksi yang bersifat pasif. la tidak memiliki hak-hak hukum terhadap pelanggar, termasuk hak untuk memperoleh ganti kerugian melalui mekanisme sistem peradilan pidana. Hukum pidana tidak mengakui adanya ganti kerugian yang disebabkan karena kejahatan, karena masalah ganti kerugian adalah persoalan individual korban dan masalah ini menjadi bagian/cakupan hukum perdata. Hukum pidana melihat dampak kejahatan hanya untuk kepentingan pembuktian di pengadilan. Jadi, peradilan pidana diselenggarakan bukanlah untuk memenuhi keinginan korban kejahatan, tetapi untuk mengadili pelanggar hukum pidana karena pelanggarannya. ${ }^{18}$

Sistem peradilan pidana yang mengandalkan pembalasan tersebut ternyata tidak dapat menjalankan fungsinya secara maksimal untuk mengontrol kejahatan, karena tidak mampu menurunkan angka kriminalitas. Tujuan ideal yang dirumuskan oleh Retributive Justice belum tampak memberikan pengaruh yang berarti dalam menjalankan fungsinya sebagai

${ }^{17}$ Mudzakkir (a), Viktimologi Studi Kasus di Indonesia, makalah pada Penataran Hukum Pidana dan Kriminologi, Surabaya, 13 Maret 2005, hal. 25.

18 Mudzakkir (b), "Posisi Hukum Korban Kejahatan Dalam Sistem Peradilan Pidana", Disertasi, (Jakarta: Universitas Indonesia, 2001), hal. 188. 
kontrol terhadap kejahatan. Mempertahankannya tanpa reserve prinsipprinsip penyelenggaraan peradilan pidana yang berbasis pada perspektif Retributive Justice tanpa mengkaji efektivitas fungsinya dalam masyarakat akan menimbulkan kerugian yang lebih besar kepada masyarakat yang hendak dilindungi oleh hukum pidana. ${ }^{19}$

Konsep retributive justice ini digunakan pula dalam menangani kasus KDRT. Pelakunya akan dijatuhkan pidana sesuai dengan perbuatannya yang melanggar hukum. Pidana yang dijatuhkan pun merupakan balasan dari apa yang dilakukannya dan sesuai dengan hukum yang berlaku. Korban KDRT hanya dianggap saksi dan pelapor saja,tidak memiliki hak untuk memilih keadilan seperti apa yang ingin dia peroleh bahkan tidak menutup kemungkinan setelah dipidananya pelaku korban malah akan semakin menderita.

Kasus KDRT merupakan kasus kejahatan yang berbeda dengan kejahatan yang lainnya. Hal ini disebabkan pelaku dan korban KDRT mempunyai hubungan yang dekat baik secara kekerabatan maupun emosional $^{20}$. Sehingga dalam menyelesaikan kasus tersebut perlu penyelesaian yang tidak hanya sekedar menghukum pelaku sesuai dengan norma yang ada tetapi juga perlu diperhatikan pemulihan korban KDRT itu sendiri.

Konsep retributive justice yang tidak memberi tempat terhadap korban dalam sistem peradilan pidana, apabila diterapkan dalam penanggulangan kasus KDRT tidaklah tepat, karena tidak dapat memberikan perlindungan terhadap korban. Mengingat korban KDRT tidak hanya dapat mengalami kerugian materiil melainkan sangat dimungkinkan mengalami kerugian immateriil.

Kerugian materiil maupun kerugian immateriil yang dialami oleh korban KDRT tidak akan diperoleh dengan menggunakan konsep retributive justice mengingat sekali lagi, konsep ini berorientasi pada pelaku tanpa memperhatikan kedudukan korban.

Namun dengan adanya semangat restorative justice yang berkembang dalam sistem hukum pidana di Indonesia membuat pergeseran konsep pemidanaan dari retributive justice ke restorative justice. ${ }^{2}$

${ }^{19}$ Mudzakkir (b), Ibid., hal. 207.

${ }^{20}$ Yang dapat menjadi korban KDRT adalah, suami, istri, anak, dan orang yang menetap di lingkungan rumah tangga. Pasal 2 Undang-undang Nomor 23 Tahun 2004 tentang Penghapusan kekerasan Dalam Rumah Tangga.

${ }^{21}$ Semangat restorative justice dapat terlihat dalam beberapa perundang-undangan diantaranya : Undang-undang Nomor 15 tahun 1995 tentang Pemasyarakatan, Undang-undang 
Pergeseran konsep pemidanaan tersebut akan mempengaruhi elemen sistem hukum yang berada di bawahnya, yaitu asas-asas hukum, konsepkonsep dasar hukum pidana dan substansi hukum pidana dan praktik sistem peradilan pidana dalam masyarakat. ${ }^{22}$

Kelompok kerja Perserikatan Bangsa Bangsa (PBB) memberikan pengertian Restorative justice sebagai suatu proses yang melibatkan semua pihak yang berhubungan dengan tindak pidana tertentu bersama-sama memecahkan masalah, dan memikirkan bagaimana menangani akibat di masa yang akan datang. ${ }^{23}$

Sebagai rasa tanggungjawab dari pelaku terhadap korban, pelaku didorong untuk memiliki rasa pertanggungjawaban dengan menunjukkan empati dan menolong untuk memperbaiki kerugian. Sebagai akibat dari perilaku menyakitkan pelaku bukan pada masa lalu pelaku. Sehingga stigma dapat dihilangkan melalui tindakan yang tepat yang didukung oleh penyesalan pelaku dan pemaafan dari korban. Proses penyelesaian bergantung pada keterlibatan langsung orang-orang yang terpengaruh oleh kejadian sehingga dimungkinkan prosesnya menjadi emosional. ${ }^{24}$

Restorative justice lebih menekankan kepada keterlibatan langsung pihak-pihak dan menuntut usaha kerja sama dengan masyarakat serta pemerintah untuk menciptakan suatu lingkungan yang harmonis sehingga korban dan pelaku dapat merekonsiliasi konflik mereka dan menyelesaikan

Nomor 31997 tentang Pengadilan Anak, Undang-undang Nomor 23 tahun 2004 tentang Penghapusan Kekerasan Dalam Rumah Tangga, Rancangan KUHP 2005.

22 Dey Ravena, "Sistem Pemasyarakatan (Pergeseran Paradigma Pembinaan Narapidana dalam Sistem Peradilan Pidana di Indonesia)", Disertasi, Program Doktor Undip, Semarang, 2007, hal. 207.

${ }^{23}$ Melani, "Membangun Sistem Hukum Pidana dari Retributif ke Restoratif", Litigasi, Volume 6 Nomor 3 Oktober 2005, terakreditasi, hal. 223.

${ }^{24}$ Bandingkan, Taufik Hidayat, "Restoratif Justice Sebuah Alternatif", Restorasi, Edisi IV/Vol 1 2005, hal. 26.

Restorative justice berbeda dengan retributive justice yang dianut sistem peradilan pidana sekarang. Perbedaan itu antara lain terdapat dalam beberapa hal, yaitu : pertama, melihat tindakan kriminal secara komprehensif. Tidak saja mendefinisikan kejahatan sebagai pelanggaran hukum semata, namun juga memahami bahwa pelaku merugikan korban, masyarakat dan bahkan dirinya sendiri. Kedua, melibatkan banyak pihak dalam merespon kejahatan, tidak hanya sebatas urusan pemerintah dan pelaku kejahatan, namun juga korban dan masyarakat. Ketiga, mengukur kesuksesan dengan cara yang berbeda, tidak hanya dari seberapa besar hukuman dijatuhkan, namun juga mengukur seberapa kerugian dapat dipulihkan atau dicegah. 
kerugian mereka dan dalam waktu yang bersamaan menimbulkan rasa aman dalam masyarakat. ${ }^{25}$

Melalui pendekatan restorative justice diharapkan pemulihan bagi korban dapat terealisasi, tujuan pemidanaan bagi pelaku akan berhasil dan ketertiban masyarakat pun dapat tercapai. Restorative justice merupakan salah satu alternatif untuk mewujudkan keadilan sesuai dengan tujuan hukum $^{26}$. Keadilan yang akan diperoleh semua pihak, baik pelaku, korban maupun masyarakat.

Konsep kejahatan menurut konsep restorative justice diberi pengertian yang lebih nyata, bahwa kejahatan adalah konflik antar orang perseorangan. Kejahatan dipahami sebagai pelanggaran, pertama dan terutama melanggar hak perseorangan dan juga melanggar hak masyarakat (kepentingan publik), kepentingan negara, dan juga sesungguhnya secara tidak langsung melanggar kepentingan pelanggar itu sendiri. ${ }^{27}$

Bila disimak karakteristik "restoratif justice model" di atas dapat ditegaskan kembali bahwa pandangannya lebih dipengaruhi paham Abolisionis yang menganggap sistem peradilan pidana mengandung masalah atau cacat struktural sehingga secara realistis harus diubah dasar-dasar struktur dari sistem tersebut.

Pergeseran konsep kejahatan dan orientasi hukum pidana yang telah diuraikan diatas, telah membawa harapan cerah untuk perlindungan hukum terhadap korban, khususnya korban Kekerasan Dalam Rumah Tangga.

Pergeseran dari retributive justice ke arah restorative justice memberikan dampak positif bagi pencegahan dan penanggulangan kejahatan. Sebagai contoh program restorative justice di negara yang sudah lebih dahulu menggunakannya seperti New Zeland, Kanada, dan Inggris, telah

${ }^{25}$ Mudzakir (b), Op. Cit, hal. 26.

${ }^{26}$ Beberapa teori tentang tujuan hukum : pertama, Teori Etis : tujuan hukum adalah keadilan. Kedua, Teori Utilitas : tujuan hukum adalah kebahagiaan. Ketiga, Teori Campuran : tujuan hukum adalah ketertiban. Pendapat lain, misalnya Mochtar Kusumaatmadja : tujuan hukum adalah keadilan secara berbeda-beda (baik isi maupun ukurannya) menurut masyarakat pada zamannya. Purnadi Purbacaraka dan Soerjono Soekanto : tujuan hukum adalah demi kedamaian hidup antar pribadi yang meliputi ketertiban ekstern antar pribadi dan ketenangan intern pribadi. Lihat Esmi Warassih, Pranata Hukum Sebuah Telaah Sosiologis, PT Suryandaru Utama, Semarang, 2005, hal 24-25.

${ }^{27}$ Mudzakkir (b), Op. Cit., hal. 210.

${ }^{28}$ M. Sholehuddin, "Sistem Sanksi dalam Hukum Pidana (Ide Double Track System dan Implementasinya)", (Jakarta: Rajawali Pers, 2004), hal. 66. 
berhasil mengurangi kejahatan dan memulihkan korban kejahatan, atau pihak-pihak yang terlibat dalam sistem peradilan pidana.

Keterlibatan korban dalam proses restorative justice meliputi perbaikan material, memperbaiki emosi termasuk harapan, perbaikan harga diri dan kehormatan, serta yang terpenting adalah partisipasi penuh dalam penanganan kasus.

Terkait dengan fairnes and satisfaction of offender, di USA, $80 \%$ mengatakan telah tercapai fairnes dari sebagian pelaku melalui mediasi program. Dan sudah menumbuhkan kejujuran dari pelaku melalui victim offender mediasi program. ${ }^{29}$ Namun perlu diperhatikan, dalam restorative justice, setiap kasus itu, harus dilaksanakan secara berbeda.

Dalam kasus KDRT, proses restorative justice bisa dijalankan melalui family group decision dengan tujuan memulihkan masyarakat. Proses restorasi dilakukan seperti penanganan masalah-masalah dalam keluarga, dilakukan proses penyembuhan melalui peer group tidak melalui terapi perorangan. $^{30}$

Konsep restorative justice tidak hanya menghadirkan pelaku dalam sistem peradilan pidana melainkan juga di dalamnya melibatkan peran korban dan masyarakat. Proses seperti itu sangat dimungkinkan untuk diterapkan dalam penyelesaian kasus-kasus KDRT.

Pelaku direstorasi melalui sistem peradilan pidana sehingga mendorong terjadinya perdamaian antara korban dan pelaku. Perdamaian itu dilakukan melalui mediasi, pertemuan, program perbaikan ekonomi dan pendidikan kejujuran. ${ }^{31}$

Dalam perdamaian yang dilakukan, korban dapat memberikan masukan tentang keadilan apa yang hendak diperolehnya. Begitu juga pelaku bisa melakukan hal-hal sebaliknya, misalnya dapat saja membayar ganti kerugian atas penderitaan yang dialami oleh korban.

Pemenuhan ganti rugi bagi korban bisa berupa restitusi atau kompensasi. Sedangkan bagi pelaku, pidana yang diberikan tidak hanya sebatas pidana penjara melainkan bisa berupa pidana kerja sosial, sehingga akan lebih bermanfaat bagi pelaku dan masyarakat.

Dalam restorative justice, korban mempunyai kesempatan untuk bertanya pada keluarganya, mengenai detil setiap peristiwa, atau kejadian,

${ }^{29}$ John Braithwaite, "Restorative Justice and Responsive Regulation", (New York: Oxford University Press), 2002, hal. 54.

${ }^{30} \mathrm{Ibid}$, hal. 66.

${ }^{31}$ Ibid, hal. 54. 
atau kejahatan yang menimpa dirinya. Apabila tidak jelas, korban bisa bertanya kembali tentang apa yang terjadi, korban juga berhak untuk berbicara tentang perasaan yang tidak enak dan luka yang diderita akibat perbuatan pelaku, namun dengan tanpa memperlihatkan kebencian terhadap pelaku melainkan harus bersikap ramah dan tersenyum.

Idealnya, dalam restorative justice, pertemuan antara pihak pelaku dan korban harus pula melibatkan pihak lain. Seperti masyarakat dengan dukungan dan perhatiannya. Oleh karena itu perbedaan utama dengan retributive justice terletak pada filosofinya yaitu kesepakatan yang menurut hukum tidak sampai melukai kepentingan masyarakat atau dengan kata lain restorative justice dilakukan dengan melalui hukum tanpa mencederai perasaan masyarakat. ${ }^{32}$

Pada saat ini, harapan tersebut bisa dilihat pada Peraturan Pemerintah Republik Indonesia Nomor 4 Tahun 2006 tentang Penyelenggaraan dan Kerjasama Pemulihan Korban Kekerasan Dalam Rumah Tangga.

Peraturan pemerintah (selanjutnya disebut PP) di atas bersinggungan dengan konsep restorative justice yang dikemukakan sebelumnya, hal ini dapat dilihat dengan diaturnya penyelenggaraan pemulihan korban KDRT yang melibatkan kerjasama dengan berbagai pihak.

Menurut PP ini pemulihan korban adalah segala upaya untuk penguatan korban kekerasan dalam rumah tangga agar lebih berdaya, baik secara fisik maupun psikis. ${ }^{33}$

Penyelenggaraan pemulihan yaitu segala tindakan yang meliputi pelayanan dan pendampingan kepada korban kekerasan dalam rumah tangga ${ }^{34}$ Penyelenggaraan pemulihan terhadap korban di atas dilaksanakan oleh instansi pemerintah dan pemerintah daerah serta lembaga sosial dengan tugas dan fungsi masing-masing, termasuk menyediakan fasilitas yang diperlukan untuk pemulihan korban. ${ }^{35}$

Untuk kepentingan pemulihan, korban berhak mendapatkan pelayanan dari tenaga kesehatan, pekerja sosial, relawan pendamping, dan/atau pemimbing rohani. ${ }^{36}$ Untuk penyelenggaraan pemulihan, pemerintah dan

${ }^{32}$ Charles K. B. Barton, "Restorative Justice (The Empowerment Model)", (Sydney: Hawkins Press, 2003), hal. 38.

33 Pasal 1 angka 1 Peraturan Pemerintah Nomor 4 Tahun 2006 tentang Penyelenggaraan dan Kerjasama Pemulihan Korban Kekerasan Dalam Rumah Tangga.

${ }^{34}$ Ibid., Pasal 1 angka 2.

${ }^{35}$ Ibid., Pasal 2 ayat (1). 
pemerintah daerah sesuai dengan tugas dan fungsi masing-masing dapat melakukan kerjasama dengan masyarakat.

Apabila melihat isi dari PP tersebut dan dibandingkan dengan konsep restorative justice, maka PP ini belum cukup untuk memberikan perlindungan dan memulihkan korban kejahatan karena hanya mengatur satu materi saja dari restorative justice yaitu pemulihan korban.

PP ini tidak menjelaskan tentang proses pemulihan yang merupakan tujuan akhir dari restorative justice. Tetap masih meletakkan korban sebagai objek. Tidak menempatkan korban untuk berpartisipasi dalam sistem peradilan pidana.

Padahal konsep restorative justice tidak hanya sekedar memulihkan korban dengan menyediakan ruang khusus atau pendampingan melainkan ada proses lain yang juga penting dan merupakan karakteristik dari konsep restorative justice sebagaimana yang sudah diterangkan di atas.

\section{Penutup}

\section{A. Simpulan}

Konsep retributive justice tidak memberikan perlindungan terhadap korban KDRT, karena konsep ini lebih berorientasi kepada pelaku, kemudian norma atau peraturan perundang-undangan yang berlaku sebagian besar tidak mengakomodasi kepentingan korban. Walaupun Undang-undang Nomor 23 Tahun 2004 tentang Penghapusan Kekerasan Dalam Rumah Tangga memberi peluang terhadap perlindungan korban, namun pada tahap implementasi belum dapat dilaksanakan mengingat PP yang sudah dikeluarkan baru mengatur satu komponen dari konsep restorative justice.

Pada dasarnya konsep restorative justice dapat diterapkan di Indonesia baik melalui atau pun tanpa sistem peradilan pidana. Hal ini dapat dilihat dari negara lain yang sudah berhasil melaksanakan konsep restorative justice. Namun dalam konteks Indonesia, banyak hal-hal yang masih perlu dipersiapkan seperti mekanisme, aturanaturan, dan pembaharuan sistem peradilan pidana.

${ }^{36}$ Pasal 6 Peraturan Pemerintah Nomor 4 Tahun 2006 tentang Penyelenggaraan dan Kerjasama Pemulihan Korban Kekerasan Dalam Rumah Tangga. 


\section{B. Saran}

Mengingat konsep kejahatan telah bergeser, orientasi hukum pidana pun tidak lagi hanya memfokuskan kepada pelaku melainkan korban sudah mulai harus diperhatikan maka sudah saatnya restorative justice dilaksanakan.

Penerapan konsep restorative justice dalam kasus-kasus tertentu perlu diperhatikan mekanisme penerapannya agar tidak mengganggu sistem yang sudah ada. Walaupun penerapan restorative justice ini baru berupa alternatif/peralihan sebelum pembaharuan sistem peradilan pidana dilakukan. 


\section{Daftar Pustaka}

\section{Buku}

Gosita, Arif. Masalah Korban Kejahatan, Jakarta: CV Akademika Pressindo, 1993.

Chaerudin dan Syarif Fadillah. Korban Kejahatan dalam Perspektif Viktimologi dan Hukum Pidana Islam, Jakarta: Grhadhika Press, 2003.

Barton, Charles K. B. Restorative Justice (The Empowerment Model), Sydney: Hawkins Press, 2003.

Mansur, Dikdik M. Arief dan Elisatris Gultom. Urgensi Perlindungan Korban Kejahatan Antara Norma dan Realita, Jakarta: PT. RajaGrafindo Persada, 2007.

Warassih, Esmi. Pranata Hukum Sebuah Telaah Sosiologis, Semarang: PT Suryandaru Utama, 2005, hlm 24-25.

Braithwaite, John. Restorative Justice and Responsive Regulation, New York: Oxford University Press, 2002.

Sholehuddin, M. Sistem Sanksi dalam Hukum Pidana (Ide Double Track System dan Implementasinya), Jakarta: Rajawali Pers, 2004.

Saraswati, Rika. Perempuan dan Penyelesaian Kekerasan dalam Rumah Tangga, Bandung: Citra Aditya Bakti, 2006.

Sunaryo, Sidik. Kapita Selekta Sistem Peradilan Pidana, Malang: UMM Pres, 2005.

Van Boven, Theo. Mereka yang Menjadi Korban, Yogyakarta: Pustaka Pelajar, 2002.

\section{Artikel}

Ravena, Dey. Sistem Pemasyarakatan (Pergeseran Paradigma Pembinaan Narapidana dalam Sistem Peradilan Pidana di Indonesia), Disertasi, Program Doktor Undip, Semarang, 2007.

Melani, "Membangun Sistem Hukum Pidana dari Retributif ke Restoratif", Litigasi, Volume 6 Nomor 3 Oktober 2005, terakreditasi.

Mudzakkir, Posisi Hukum Korban Kejahatan Dalam Sistem Peradilan Pidana, Disertasi, Universitas Indonesia, Jakarta, 2001. 
Mudzakkir, Viktimologi Studi Kasus di Indonesia, Penataran Hukum Pidana dan Kriminologi, Surabaya, 13 Maret 2005.

Hidayat, Taufik "Restoratif Justice Sebuah Alternatif", Restorasi, Edisi IV/Vol 12005.

\section{Peraturan}

Kitab Undang-undang Hukum Acara Pidana.

Kitab Undang-undang Hukum Pidana.

Undang-undang Nomor 23 Tahun 2004 tentang Penghapusan Kekerasan Dalam Rumah Tangga.

Peraturan Pemerintah Nomor 4 Tahun 2006 tentang Penyelenggaraan dan Kerjasama Pemulihan Korban Kekerasan Dalam Rumah Tangga.

Deklarasi Penghapusan Kekerasan terhadap Perempuan, 1993.

The Declaration of Basic Principles of Justice for Victims of Crime and Abuse of Power, PBB (1985).

\section{Internet}

http://gp-ansor.org.

www.suaramerdeka.com.

www.kompas.com.

http://books.google.co.id. 